\title{
Identifikasi sedentary behaviour di masa pandemic covid-19: narrative review
}

\author{
Riska Risty Wardhani1 ${ }^{*}$, Nurul Muflihah ${ }^{2}$ \\ ${ }^{1}$ Universitas 'Aisyiyah Yogyakarta, Jalan Siliwangi No.63 Nogotirto Gamping Sleman, Yogyakarta 55292, Indonesia \\ ${ }^{2}$ Universitas ‘Aisyiyah Yogyakarta, Jalan Siliwangi No.63 Nogotirto Gamping Sleman, Yogyakarta 55292, Indonesia \\ riskaristywardhani@unisayogya.ac.id*; nurulmuflikhah1@gmail.com \\ *Corresponding Author
}

Received: 10 Februari 2021; Accepted: 16 Maret 2021; Published: 1 April 2021

\begin{abstract}
ABSTRAK
Pembatasan sosial, isolasi dan karantina merupakan salah satu cara untuk mencegah penyebaran COVID-19 yang lebih luas. Meskipun jarak sosial dapat memperlambat penyebaran COVID-19, tetapi orang akan menghabiskan sebagian besar waktunya di rumah dan tidak aktif secara fisik atau membentuk perilaku menetap atau sedentary behaviour. Tujuan penelitian ini untuk mengidentifikasi adanya perilaku menetap atau sedentary behaviour di masa pandemic COVID-19. Metode penelitian ini menggunakan metode Narrative Review. Pencarian jurnal melalui portal jurnal online seperti Google Scholar, PubMed, dan MedLine sesuai dengan kriteria inklusi. Hasil penelitian ini berdasarkan reviewterhadap 11 jurnal dari berbagai negara yang berbeda,semua mengidentifikasi terjadinya sedentary behaviour di masa pandemic COVID-19. Kesimpulan penelitian membuktikan adanya identifikasi sedentary behviour di masa pandemic COVID-19.
\end{abstract}

\section{KEYWORDS}

sedentary

behaviour;

pandemic covid-

19; aktivitas fisik

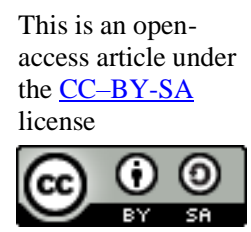

\section{Pendahuluan}

Pada tanggal 30 Januari 2020, Organisasi Kesehatan Dunia (WHO) menyatakan bahwa wabah virus korona baru adalah darurat kesehatan masyarakat yang menjadi perhatian internasional. Selanjutnya pada tanggal 11 Maret 2020Organisasi Kesehatan Dunia (WHO)resmi mengumumkan wabah COVID-19 sebagai pandemi global (Salvatore et al., 2020). Dalam waktu kurang dari tiga bulan, COVID-19 telah menginfeksilebih dari 126.000 orang di 123 negara, dari Asia, Eropa, AS, hingga Afrika Selatan.

Sejak itu, upaya yang belum pernah terjadi sebelumnya telah dilakukan oleh pemerintah di seluruh dunia untuk memperlambat kejadian infeksi. Upaya yang dilakukan oleh pemerintah Hong Kong, misalnya, pembatasan masuk perbatasan, karantina dan isolasi untuk kasus dan kontak terhadap kasus, serta penutupan sekolah yang mengakibatkan gangguan besar pada rutinitas seharihari. Peningkatan jumlah kasus di Hong Kong pada akhir Maret 2020 selanjutnya mendorong pemerintah untuk melakukanlangkah-langkah yang lebih ketattermasuk penutupan fasilitas rekreasi danfasilitas budaya, dan melanjutkan proses pembelajaran kepada siswa melalui platform online (Zheng et al., 2020).

Di Indonesia sendiri Presiden Joko Widodo menegaskan bahwa kebijakanuntuk beraktivitas produktif di rumah perlu dilakukan untuk menekan penyebaran virus corona atau penyakit COVID-19. Adapun, aktivitas itu terutama terkait bekerja, belajar, juga beribadah. Hal ini disampaikan Presiden Jokowi dalam konferensi pers di Istana Bogor pada Senin (16/3/2020) (Ihsanuddin, 2020).

Di Perancis dan Switzerland tindakan lockdown termasuk penutupan gym, pembatasan pergerakan publik, dan pengurangan perjalanan, telah mengganggu rutinitas harian secara dramatis (Cheval et al., 2020). 
Pemerintah Italia menetapkan kebijakan menetapkan jarak sosial, penutupan sekolah dan universitas, dan penangguhan acara sosial apa pun, termasuk kompetisi olahraga profesional dan non-profesional. Kemudian, penangguhan semua aktivitas di gym, pusat olahraga dan kolam renang juga diberlakukan (Giustino et al., 2020).

Aturan ketat untuk mengendalikanpenyebaran SARS-CoV-2 juga diberlakukan di Australia yaitu dengan pembatasan pergerakan geografis, seperti perintah untuk tetap di rumah kecuali jika perlu pergi (misalnya untuk berbelanja atau berolahraga) dan perintah untuk tidak meninggalkan rumah untuk alasan apapun selain keadaan darurat bagi mereka yang diduga terjangkit SARSCoV-2 (Kunstler, Slattery, Grundy, Goodwin, \&Saeri, 2020).

Seperti halnya di negara lain, Yordania juga memberlakukan kebijakan penangguhan sekolah, larangan pertemuan publik, penutupan perbatasan, bandara, bisnis, dan tempat ibadah, dan pembatasan perjalanan local (Alomari, Khabour, \& Alzoubi, 2020). Sedangkan di Brazil untuk menghambat kecepatan penularan dan kontaminasi yang cepat, otoritas publik lokal mengeluarkan dekrit, dengan hukuman bagi perusahaandan individu yang tidak mematuhi

kebijakan pemerintah (Malta et al., 2020).

Tanggap darurat kesehatan masyarakat untuk memperlambat transmisi COVID-19 diberlakukan di Kanada dengan penutupan paksa fasilitas pendidikan danpenitipan anak, bisnis yang tidak penting, dan fasilitas rekreasi pribadi dan publik (misalnya, taman bermain, peralatan olahraga luar ruangan, dan lapangan olahraga), menghindari tempat keramaian, menghindari sosialisasi umum, membatasi kontak dengan individu berisiko tinggi, dan menjaga jarak 2 meter dari orang lain, meninggalkan perjalanan internasional, dan karantina sendiri jika mereka mengalami gejala (McCormack, Doyle- Baker, Petersen, \& Ghoneim, 2020).

\section{Pandemic COVID-19 dan Sedentary behaviour}

Meskipun langkah-langkah pembatasan sangat direkomendasikan dan penting untuk mengurangi penyebaran COVID-19, namun bisa mengakibatkan perilaku tidak sehat seperti gaya hidup yang tidak banyak bergerak, menjaga jarak dengan bekerja atau belajar dari rumah atau dalam kasus lain, mengisolasi diri dengan karantina yang ketat. Yang harus menjadi perhatian adalah potensi efek aktivitas fisik berkurang dan meningkatnya perilaku menetap ataukurang gerak (SB) (Zheng et al., 2020).

Dalam keadaan normal, gaya hidup yang tidak banyak bergerak termasuk aktivitas fisik dan sedentary behaviour (perilaku menetap) yang berkepanjangan telah diidentifikasi sebagai masalah pada orang dewasa. Organisasi Kesehatan Dunia memperkirakan bahwa ketidakaktifan fisik menyebabkan kira- kira $22 \%$ penyakit jantung iskemik, $10-16 \%$ diabetes, dan 2 juta kematian di seluruh dunia setiap tahun. Sedentary behaviour atau perilaku menetap adalah 'waktu duduk' atau sekadar aktivitas fisik tingkat rendah atau kegiatan yang mengacu pada segala jenis aktivitas yang dilakukan di luar waktu tidur, dengan karakteristik keluaran kalori sangat sedikit. Perilaku menetap meliputi aktivitas seperti berbaring, duduk, menonton televisi, menggunakankomputer dan bentuk hiburan berbasislayar lainnya. Menurut Kemenkes kegiatan sedentari (sedentary) adalah kegiatan yang mengacu pada segala jenisaktivitas yang dilakukan di luar waktu tidur, dengan karakteristik keluaran kalori sangat sedikit yakni <1.5 METs (P2PTM Kemenkes RI).

\section{Metode Penelitian}

Metode penelitian yang digunakan adalah narrative review dengan kriteria inklusi artikel yang berisi full dan free full text, dipublish mulai tahun 2019, berbahasa Indonesia dan Inggris, membahas identifikasi adanya sedentary behaviour di masa pandemic COVID-19. Penelusuran artikel menggunakan database Google Schoolar, PubMed, dan MedLine dengan pola PEOs (Population, Exposure (s), Outcome). Jurnal yang didapatkan dalam pencarian literatur adalah PubMed 16 artikel, Google Scholar 3530 artikel, dan MedLine ada 3 artkel. Setelah diseleksi sesuai kriteria inklusi didapatkan artikel sejumlah 35, dan hasil akhir artikel yang akan dianalisa sejumlah 11. 


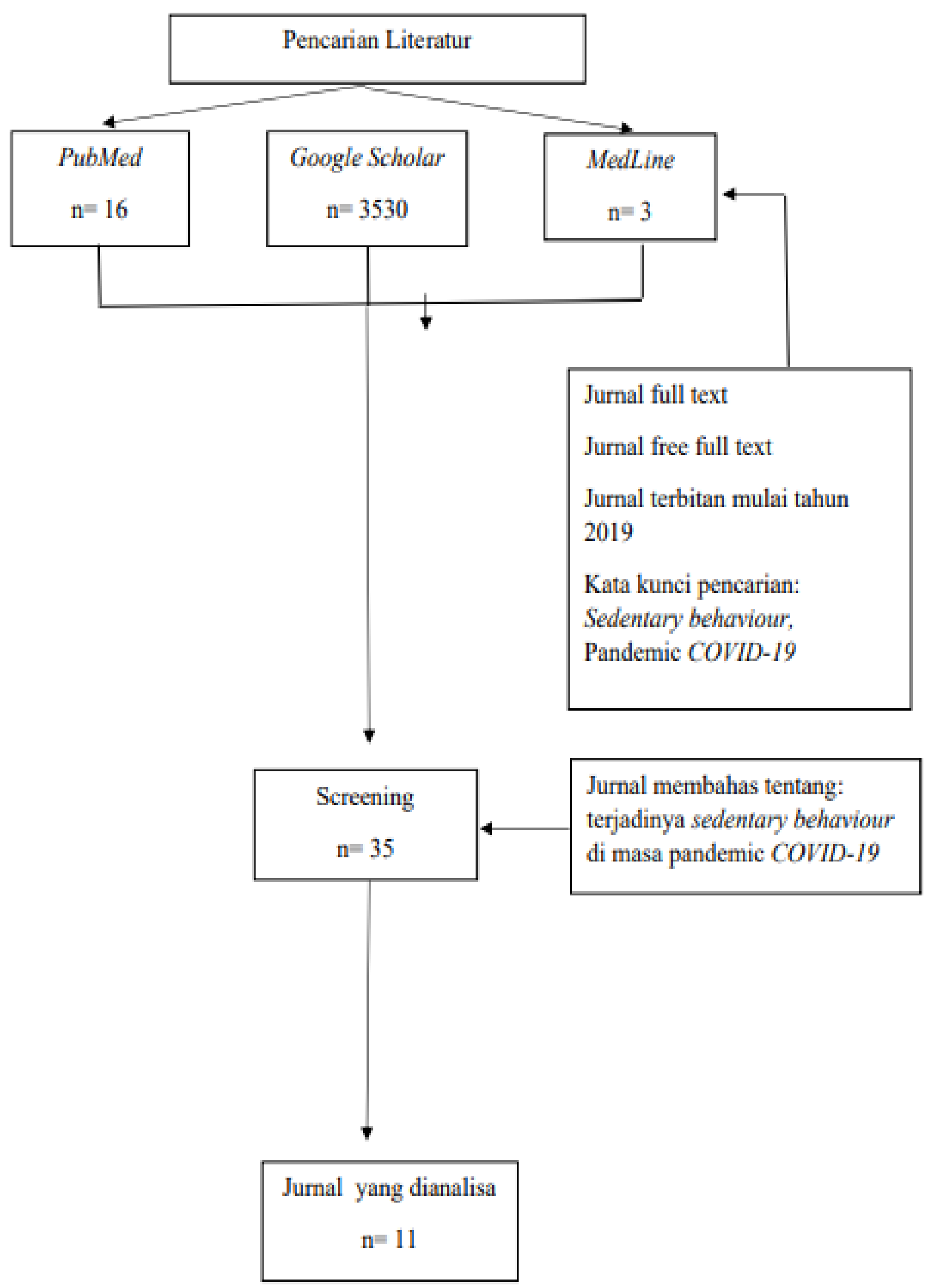




\section{Hasil Penelitian}

\begin{tabular}{|c|c|c|c|c|}
\hline No & $\begin{array}{l}\text { Jurnal/ } \\
\text { Artikel }\end{array}$ & Tujuan Penelitian & Pengumpulan Data & Hasil Penelitian \\
\hline 1 & $\begin{array}{l}\text { Cheval et al., } \\
\text { (2020) dari } \\
\text { Swit- zerland }\end{array}$ & $\begin{array}{l}\text { Untuk menilai apakah } \\
\text { ada perubahan dalam } \\
\text { aktivitas fisik dan } \\
\text { sedentary beviour } \\
\text { selama } r \text { lockdown } \\
\text { COVID-19 dikaitkan } \\
\text { dengan Kesehatan } \\
\text { mental dan fisik. Jenis } \\
\text { penelitian Obser- } \\
\text { Vational longitudi- al } \\
\text { study }\end{array}$ & 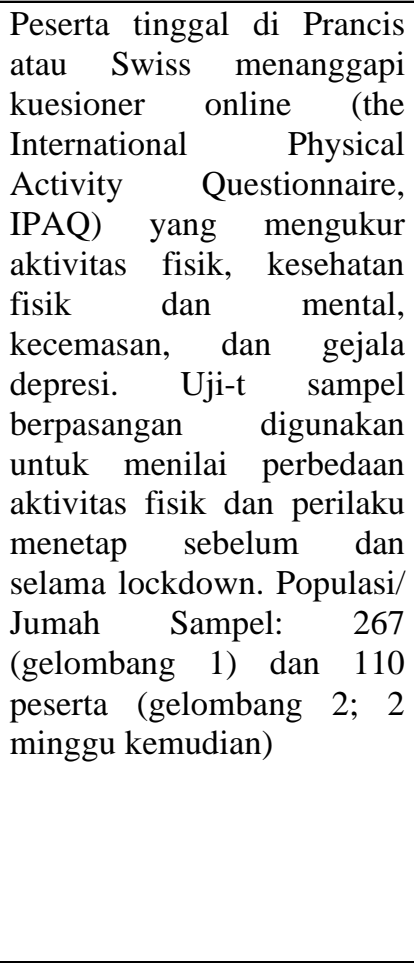 & 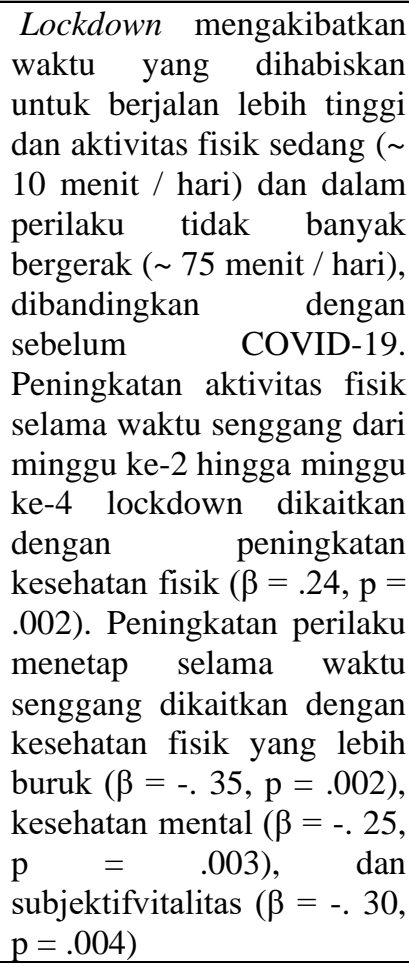 \\
\hline 2 & $\begin{array}{l}\text { Giustino et al., } \\
\text { (2020) dari } \\
\text { Italia }\end{array}$ & 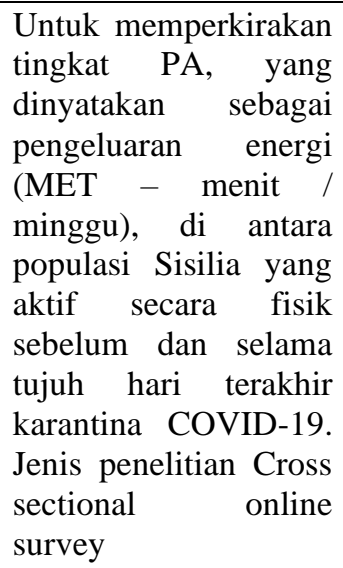 & 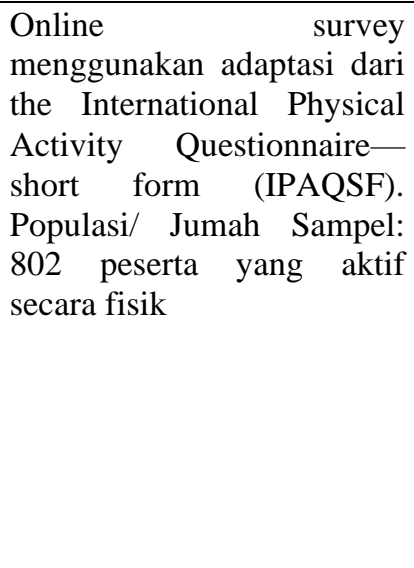 & $\begin{array}{l}\text { Penurunan yang signifikan } \\
\text { dari total pengeluaran } \\
\text { energi mingguan selama } \\
\text { karantina COVID-19 (p } \\
<0,001 \text { ). Karantina saat ini } \\
\text { berdampak negatif pada } \\
\text { praktik PA, dengan dampak } \\
\text { yang lebih besar pada pria } \\
\text { dan subjek yang kelebihan } \\
\text { berat badan }\end{array}$ \\
\hline 3 & $\begin{array}{c}\text { Rahman, } \\
\text { Islam, } \\
\text { Bishwas, } \\
\text { Moonajilin, \& } \\
\text { Gozal, (2020) } \\
\text { dari Bangla } \\
\text { desh }\end{array}$ & $\begin{array}{lr}\text { Untuk mengetahui } \\
\text { prevalensi } \\
\text { ketidakaktifan fisik } \\
\text { dan perilaku menetap } \\
\text { selama pandemi } \\
\text { COVID-19 di } & \text { antara } \\
\text { masyarakat } & \\
\text { Bangladesh. } & \text { Jenis } \\
\text { penelitian } & \text { Online } \\
\text { cross sectional survey }\end{array}$ & $\begin{array}{l}\text { Survei online dilakukan } \\
\text { selama } 10 \text { hari pada Juni } \\
2020 \text { selama pandemi } \\
\text { COVID-19 menggunakan } \\
\text { adaptasi dari IPAQSF untuk } \\
\text { menilai aktivitas fisik dan } \\
\text { perilaku menetap pada saat } \\
\text { jumlah kasus yang baru } \\
\text { didiagnosis meningkat, dan } \\
\text { lockdown masih dilakukan. } \\
\text { Populasi/ Jumah Sampel: } \\
\text { 2028 peserta }\end{array}$ & $\begin{array}{l}\text { Tingkat prevalensi } \\
\text { ketidakaktifan fisik ( }(<600 \\
\text { MET-menit / minggu) dan } \\
\text { perilaku menetap yang } \\
\text { tinggi ( } \geq 8 \text { jam / hari) di } \\
\text { antara orang Bangladesh } \\
\text { masing-masing adalah } \\
37,9 \% \text { dan } 20,9 \% \text {. } \\
\text { Prevalensi ketidakaktifan } \\
\text { fisik secara signifikan lebih } \\
\text { tinggi pada orang muda } \\
(42,5 \%) \text { dibandingkan } \\
\text { dengan orang yang lebih tua } \\
\text { dari } 25 \text { tahun }(27,7 \%)\end{array}$ \\
\hline
\end{tabular}




\begin{tabular}{|c|c|c|c|c|}
\hline 4 & $\begin{array}{l}\text { Bachtiar, } \\
\text { Condrowati, } \\
\text { Utari, \& } \\
\text { Maharani, } \\
\text { (2020) dari } \\
\text { Indonesia }\end{array}$ & $\begin{array}{l}\text { Untuk } \\
\text { mengidentifikasi } \\
\text { tingkat aktivitas fisik } \\
\text { masyarakat Indonesia } \\
\text { selamar pandemi } \\
\text { COVID-19. Jenis } \\
\text { penelitian } \quad \text { Cross } \\
\text { Sectional Descriptiv e } \\
\text { Study }\end{array}$ & 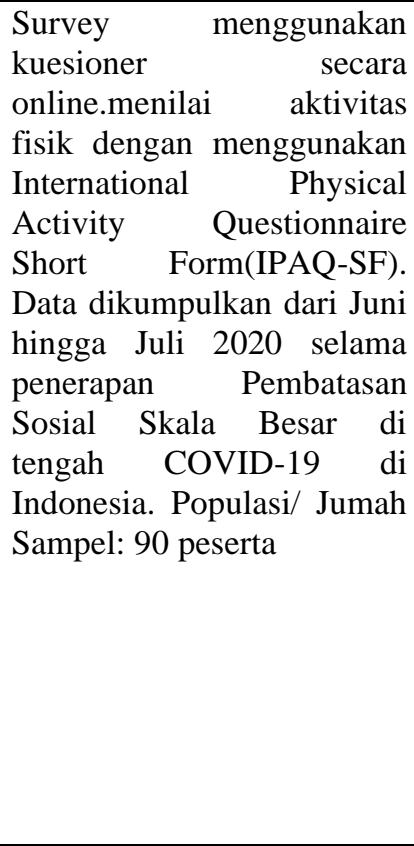 & $\begin{array}{l}\text { Ditemukan bahwa hampir } \\
\text { setengah dari peserta } \\
\text { terlibat dalam aktivitas fisik } \\
\text { tingkat rendah, ada } 41 \\
(45,6 \%) \text { peserta termasuk } \\
\text { dalam kategori aktivitas } \\
\text { fisik tingkat rendah, } 20 \\
(22,2 \%) \text { peserta di kategori } \\
\text { sedang, dan } 29 \text { (32,2\%) } \\
\text { peserta dalam kategori } \\
\text { tinggi. Mayoritas peserta } \\
\text { menghabiskan } 4 \text { hingga } 6 \\
\text { jam untuk bekerja dan } \\
\text { duduk setiap hari selama } \\
\text { tinggal di rumah. } \\
\text { Kesimpulan-nya, penerapan } \\
\text { Peraturan Pembatasan } \\
\text { Sosial Skala Besar dapat } \\
\text { meningkatkan risiko fisik } \\
\text { tidak aktif dan perilaku } \\
\text { menetap }\end{array}$ \\
\hline 5 & $\begin{array}{c}\text { Dunton, Do, \& } \\
\text { Wang, (2020) } \\
\text { dari US }\end{array}$ & $\begin{array}{l}\text { Studi ini meneliti efek } \\
\text { pandemi COVID-19 } \\
\text { pada PA dan perilaku } \\
\text { sedentary (SB) anak- } \\
\text { anak di A.S . Jenis } \\
\text { Penelitian Prospectiv } \\
\text { e survey }\end{array}$ & $\begin{array}{l}\text { Orang tua dan wali resmi } \\
\text { anak-anak A.S. (usia 5-13) } \\
\text { direkrut melalui } \\
\text { pengambilan sampel yang } \\
\text { mudah dan menyelesaikan } \\
\text { survei online antara } 25 \\
\text { April - } 16 \text { Mei 2020. } \\
\text { Tindakan yang dilakukan } \\
\text { yaitu melakukan penilaian } \\
\text { PA dan SB dengan } \\
\text { menunjukkan waktu yang } \\
\text { dihabiskan di } 11 \text { jenis PA } \\
\text { umum dan } 12 \text { jenis SB } \\
\text { umum untuk anak-anak. } \\
\text { Orang tua juga melaporkan } \\
\text { persepsi perubahan tingkat } \\
\text { PA dan SB antara pra- } \\
\text { COVID19 (Februari 2020) } \\
\text { dan periode awal COVID- } \\
19 \text { (April - Mei 2020). } \\
\text { Populasi/ Jumah Sampel: } \\
211 \text { peserta }\end{array}$ & $\begin{array}{l}\text { Secara keseluruhan, hasil } \\
\text { dari penelitian ini } \\
\text { menunjukkan anak-anak AS } \\
\text { melakukan lebih sedikit PA } \\
\text { dan terlibat dalam lebih } \\
\text { banyak SB selama periode } \\
\text { awal COVID-19 } \\
\text { dibandingkan dengan } \\
\text { sebelum pandemi. }\end{array}$ \\
\hline
\end{tabular}




\begin{tabular}{|c|c|c|c|c|}
\hline 6 & $\begin{array}{c}\text { Kunstler, } \\
\text { Slattery, } \\
\text { Grundy, } \\
\text { Goodwin, \& } \\
\text { Saeri, (2020) } \\
\text { dari Australia }\end{array}$ & \begin{tabular}{l} 
Untuk \\
mengidentifikasi \\
persentase orang \\
dewasa Australia yang \\
melakukan aktivitas \\
fisik dan perilaku \\
menetap relama \\
pandemi r novel \\
coronavirus 2019. \\
Jenis penelitian Cross \\
\multicolumn{2}{l}{ sectional survey }
\end{tabular} & \begin{tabular}{lr} 
Orang dewasa Australia \\
$(\geq 18$ tahun) diminta untuk \\
mengisi kuesioner & $15-20$ \\
menit pada $21-23$ & April \\
2020, & \multicolumn{2}{c}{ untuk } \\
mengidentifikasi PA dan \\
perilaku menetap mereka \\
selama pandemi & virus \\
corona & 2019. Populasi/ \\
Jumah & Sampel: 1084 \\
peserta &
\end{tabular} & $\begin{array}{l}\text { Mayoritas responden tidak } \\
\text { memenuhi komponen } \\
\text { aerobik }(\mathrm{n}=756,70 \%) \text { atau } \\
\text { kekuatan }(\mathrm{n}=649,60 \%) \\
\text { sesuai pedoman. Mayoritas } \\
\text { responden }(\mathrm{n}=609,58 \%) \\
\text { berpartisipasi dalam } \\
\text { aktivitas menetap rendah } \\
\text { waktu ( ( } 9 \text { jam / hari). } \\
\text { Warga Australia berusia 18- } \\
29 \text { tahun berpartisipasi } \\
\text { dalam waktu yang lebih } \\
\text { banyak duduk dibandingkan } \\
\text { orang Australia berusia } 60- \\
69 \text { tahun (50\% dan 68\% } \\
\text { menghabiskan <9 jam } \\
\text { duduk setiap hari, masing- } \\
\text { masing) }\end{array}$ \\
\hline 7 & $\begin{array}{l}\text { Zheng et al., } \\
(2020) \text { dari } \\
\text { China }\end{array}$ & $\begin{array}{l}\text { Untuk mengetahui (1) } \\
\text { tingkat aktivitas fisik } \\
\text { (PA), perilaku } \\
\text { sedentary (SB), dan } \\
\text { tidur pada dewasa } \\
\text { muda selama Epidemi } \\
\text { COVID-19, dan (2) } \\
\text { perubahan perilaku ini } \\
\text { sebelum dan selama } \\
\text { pandemi. } \\
\text { penelitian Jenis } \\
\text { Sectional Cross } \\
\text { Longitudin al Study }\end{array}$ & 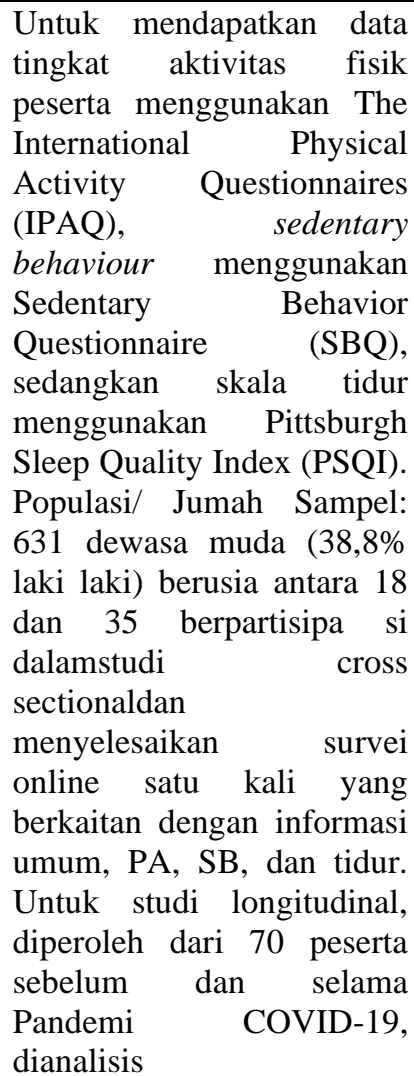 & $\begin{array}{l}\text { Peserta terlibat dalam PA } \\
\text { rendah, SB tinggi, dan tidur } \\
\text { dengan durasi lama Selama } \\
\text { pandemi COVID-19 dan } \\
\text { terjadi penurunan PA yang } \\
\text { signifikan sekaligus } \\
\text { peningkatan waktu yang } \\
\text { dihabiskan untuk SB dan } \\
\text { tidur selama wabah } \\
\text { COVID-19. }\end{array}$ \\
\hline
\end{tabular}




\begin{tabular}{|c|c|c|c|c|}
\hline 8 & $\begin{array}{l}\text { Alomari, } \\
\text { Khabour, \& } \\
\text { Alzoubi, } \\
\text { (2020) dari } \\
\text { Qatar }\end{array}$ & $\begin{array}{lr}\text { Untuk memeriksa } \\
\text { perubahan PA dan SB } \\
\text { selama pandemic } \\
\text { COVID-19. } \\
\text { penelitian Jenis } \\
\text { sectional survey }\end{array}$ & $\begin{array}{lr}\text { Orang dewasa } & \text { Yordania } \\
\text { (usia> } 18 \text { tahun } & \text { diminta } \\
\text { berpartisipasi } & \text { melalui } \\
\text { kuesioner online } & \text { selama } \\
\text { April dan Mei } 2020 . & \text { Prilasi/ Jumah Sampel: } \\
\text { Popula } & \text { S44 peserta }\end{array}$ & $\begin{array}{l}\text { Mayoritas }(41,8-42,2 \%) \\
\text { dari peserta melaporkan } \\
\text { "penurunan" ( } \mathrm{p}<0,05) \\
\text { dalam berjalan, jogging, } \\
\text { dan olahraga sementara } \\
\text { mayoritas (46,3-53,1\%) } \\
\text { melaporkan "tidak ada } \\
\text { perubahan" ( } \mathrm{p}<0,05) \\
\text { dalam berenang, bersepeda, } \\
\text { dan angkat beban. } \\
\text { Berkenaan dengan SB, } \\
\text { sebagian besar peserta } \\
\text { melaporkan "peningkatan" } \\
\text { dalam menonton TV } \\
(72,3 \%) \text { menggunakan } \\
\text { elektronik (82,7\%), dan } \\
\text { mengakses media sosial } \\
(81,9 \%)\end{array}$ \\
\hline 9 & $\begin{array}{l}\text { Malta et al., } \\
(2020) \text { dari } \\
\text { Brazil }\end{array}$ & $\begin{array}{l}\text { Untuk } \\
\text { mendeskripsikan } \\
\text { perubahan gaya hidup } \\
\text { terkait konsumsi } \\
\text { tembakau dan alkohol, } \\
\text { asupan makanan dan } \\
\text { aktivitas fisik, dalam } \\
\text { periode pembatasan } \\
\text { sosial akibat pandemi } \\
\text { COVID-19. Jenis } \\
\text { penelitian Cross } \\
\text { sectional study }\end{array}$ & $\begin{array}{l}\text { Pengumpulan data } \\
\text { dilakukan melalui kuesioner } \\
\text { online terhadap peserta } \\
\text { dengan usia } \geq 18 \text { tahun. } \\
\text { Populasi/ Jumah Sampel: } \\
213 \text { peserta }\end{array}$ & \begin{tabular}{lrr} 
Peserta & \multicolumn{2}{c}{ melaporkan } \\
penurunan dalam praktik \\
aktivitas fisik dan \\
peningkatan waktu yang \\
dihabiskan menggunakan \\
komputer atau tablet atau \\
menonton TV, asupan \\
makanan cepat saji, jumlah \\
rokok yang dihisap dan \\
konsumsi \\
beralkohol minuman \\
pembatasan sosial
\end{tabular} \\
\hline 10 & $\begin{array}{l}\text { RomeroBlanco } \\
\text { et al., (2020) } \\
\text { dari Spanyol }\end{array}$ & $\begin{array}{lr}\text { Untuk mengevaluasi } \\
\text { aktivitas fisik dan } \\
\text { perilaku menetap } \\
\text { siswa sebelum dan } \\
\text { selama lockdown. } \\
\text { Jenis penelitian } \\
\text { Observati onal, cross } \\
\text { sectional,pre-post } \\
\text { study with two cut-off } \\
\text { points }\end{array}$ & $\begin{array}{l}\text { Aktivitas fisik dan waktu } \\
\text { duduk yang diukur dengan } \\
\text { International Physical } \\
\text { Activity Questionnaire } \\
\text { Short Form (IPAQ SF) pada } \\
\text { 15-30 Januari 2020 dan 1- } \\
\text { 15 April 2020. Populasi/ } \\
\text { Jumah Sampel: } 213 \text { peserta }\end{array}$ & $\begin{array}{l}\text { Peningkatan aktivitas fisik } \\
\text { dan waktu duduk secara } \\
\text { global }\end{array}$ \\
\hline 11 & $\begin{array}{l}\text { McCormack, } \\
\text { Doyle-Baker, } \\
\text { Petersen, \& } \\
\text { Ghoneim, } \\
\text { (2020) dari } \\
\text { Kanada }\end{array}$ & $\begin{array}{lr}\text { untuk mengetahui } \\
\text { hubungan } & \text { antara } \\
\text { kecemasan orang tua } \\
\text { COVID-19 dengan } \\
\text { aktivitas fisik dan } \\
\text { perilaku menetap pada } \\
\text { anak usia sekolah. - 17 } \\
\text { tahun) dan; untuk } \\
\text { menggambarkan pola } \\
\text { perilaku di antara anak } \\
\text { usia sekolah dalam } \\
\text { kaitannya rangan } \\
\text { tanggap dengar } \\
\text { kesehatan masyarakat } \\
\text { COVID-1. } \\
\text { penelitian } & \text { Jenis } \\
\text { sectional } & \text { Cross }\end{array}$ & $\begin{array}{l}\text { Kuesioner online dengan } \\
\text { sampel acak antara April } \\
\text { dan Juni 2020. Populasi/ } \\
\text { Jumah Sampel: } 345 \text { peserta }\end{array}$ & $\begin{array}{l}\text { Sepertiga orang tua }(35,7 \%) \\
\text { melaporkan sangat cemas } \\
\text { tentang COVID-19. Selama } \\
\text { periode ini, sebagian besar } \\
\text { anak meningkat dalam } \\
\text { menonton televisi }(58,8 \%) \text {, } \\
\text { komputasi atau game } \\
(56,4 \%) \text {, dan penggunaan } \\
\text { perangkat berbasis layar } \\
(75,9 \%) \text { Setengah dari } \\
\text { anak-anak mengalami } \\
\text { penurunan bermain di } \\
\text { taman }(52,7 \%) \text { dan di ruang } \\
\text { publik (53,7\%). Aktivitas } \\
\text { fisik di rumah meningkat } \\
(48,8 \%) \text { atau tidak berubah } \\
(32,9 \%)\end{array}$ \\
\hline
\end{tabular}


Peningkatan sedentary behaviour dapat menimbulkan dampak negatif terhadap kesehatan. Berdasarkan pedoman aktivitas fisik kesehatan masyarakat (WHO, 2010), Penurunan sekitar 6 menit aktivitas fisik yang kuat dalam sehari setara dengan sekitar $60 \%$ dari 75 menit aktivitas fisik yang kuat per minggu.

Gaya hidup yang tidak aktif dan tidak banyak bergerak terkait erat dengan risiko penyakit kardiovaskular yang lebih tinggi, peningkatan risiko obesitas, tekanan darah tinggi, kadar kolesterol darah tinggi, dan diabetes tipe 2 .

Melihat dampak yang merugikan terhadap kesehatan dengan adanya sedentary behaviour, maka perlu diupayakan langkah-langkah untuk mengurangi dampak negatif tersebut. Langkah yang bisa dilakukan diantaranya menerapkan kebiasaan baru yang menumbuhkan gaya hidup yang lebih aktif, edukasi untuk promosi kesehatan dengan membuat penduduk sadar akan perlunya mempertahankan keadaan aktif. Dari WHO dan komunitas profesional lainnya merekomendasikan program latihan yang spesifik dan program latihan rumahan untuk mempertahankan gaya hidup aktif secara fisik selama pandemic. Edukasi untuk tingkat aktivitas fisik minimum yang disarankan 600 MET menit / minggu untuk mengurangi risiko kanker payudara, kanker usus besar, penyakit jantung iskemik, stroke iskemik, dan diabetes. Untuk dapat mempertahankan aktifitas fisik di rumah dengan kelas latihan online sehingga membantu orang melakukan lebih banyak aktivitas fisik dan penguatan selama pembatasan dan tinggal di rumah dan penguatan selama pembatasan dan tinggal di rumah.

\section{Kesimpulan}

Sebagai kesimpulan, penelitian ini menunjukkan bahwa pandemic COVID-19 telah memunculkan perilaku sedentary di berbagai negara yang berdampak. Oleh karena itu diperlukan kebijakan agar masyarakat tetap melakukan gaya hidup akif dan banyak bergerak selama pandemic COVID -19. Penelitian ini masih banyak kekurangannya, sehingga ke depannya diharapkan ada yang mengembangkan penelitian selanjutnya.

\section{References}

Alomari, M. A., Khabour, O. F., \& Alzoubi, K. H. (2020). Changes in physical activity and sedentary behavior amid confinement: The bksq-covid-19 project. Risk Management and Healthcare Policy, 13, 1757-1764. https://doi.org/10.2147/RMHP.S268320

Alomari, M. A., Khabour, O. F., \& Alzoubi, K. H. (2020). Changes in physical activity and sedentary behavior amid confinement: The bksq-covid-19 project. Risk Management and Healthcare Policy, 13, 1757-1764. https://doi.org/10.2147/RMHP.S268320

Bachtiar, F., Condrowati, Utari, D., \& Maharani, F. T. (2020). Physical Activity Levels of Adults During Covid-19 Quarantine in Indonesia: A Cross- Sectional Descriptive Study. 30(Ichd), 267-273. https://doi.org/10.2991/ahsr.k.201125.0 47

Cheval, B., Sivaramakrishnan, H., Maltagliati, S., Fessler, L., Forestier, C., Sarrazin, P., ... Boisgontier, M. P. (2020). Relationships between changes in self-reported physical activity, sedentary behaviour and health during the coronavirus (COVID-19) pandemic in France and Switzerland. Journal of Sports Sciences, 00(00), 1-6. https://doi.org/10.1080/02640414.2020. 1841396

Cheval, B., Sivaramakrishnan, H., Maltagliati, S., Fessler, L., Forestier, C., Rahman, M. E., Islam, M. S., Bishwas, M. S., Moonajilin, M. S., \& Gozal, D. (2020). Physical inactivity and sedentary behaviors in the Bangladeshi population during the COVID-19 pandemic: An online cross-sectional survey. Heliyon, 6(10), e05392. https://doi.org/10.1016/j.heliyon.2020.e 05392

Dunton, G. F., Do, B., \& Wang, S. D. (2020). Early effects of the COVID-19 pandemic on physical activity and sedentary behavior in children living in the U.S. BMC Public Health, 20(1), 1- 13. https://doi.org/10.1186/s12889-020-09429-3

Giustino, V., Parroco, A. M., Gennaro, A., Musumeci, G., Palma, A., \& Battaglia, G. (2020). Physical activity levels and related energy expenditure during COVID-19 quarantine among the sicilian active population: A cross- sectional online survey study. Sustainability (Switzerland), 12(11). https://doi.org/10.3390/su12114356 
Kunstler, B. E., Slattery, P., Grundy, E., Goodwin, D., \& Saeri, A. (2020). Physical activity and sedentary behaviour during the COVID-19 pandemic: An Australian population study Running. 3800, 1-25.

Malta, D. C., Szwarcwald, C. L., Barros, M. B. de A., Gomes, C. S., Machado, Í. E., Souza Júnior, P. R. B. de, ... Gracie, R. (2020). A pandemia da COVID-19 e as mudanças no estilo de vida dos brasileiros adultos: um estudo transversal, 2020. Epidemiologia e Servicos de Saude: Revista Do Sistema Unico de Saude Do Brasil, 29(4), e2020407. https://doi.org/10.1590/S1679- 49742020000400026

McCormack, G. R., Doyle-Baker, P. K. Bachtiar, F., Condrowati, Utari, D., \& Maharani, F. T. (2020). Physical Activity Levels of Adults During Covid-19 Quarantine in Indonesia: A Cross- Sectional Descriptive Study. 30(Ichd), 267-273. https://doi.org/10.2991/ahsr.k.201125.0 47

Petersen, J. A., \& Ghoneim, D. (2020). Parent anxiety and perceptions of their child's physical activity and sedentary behaviour during the

Preventive Medicine Reports, COVID-19 pandemic in Canada. https://doi.org/10.1016/j.pmedr.2020.10 127

Romero-Blanco, C., Rodríguez- Almagro, J., Onieva-Zafra, M. D., Parra- Fernández, M. L., PradoLaguna, M. D. C., \& Hernández-Martínez, A. (2020). Physical activity and sedentary lifestyle in university students: Changes during confinement due to the covid-19 pandemic. International Journal of Environmental Research and Public Health, 17(18), 1-13. https://doi.org/10.3390/ijerph17186567

Sarrazin, P., ... Boisgontier, M. P. (2020). Relationships between changes in self-reported physical activity, sedentary behaviour and health during the coronavirus (COVID-19) pandemic in France and Switzerland. Journal of Sports Sciences,

00(00), 1-6. https://doi.org/10.1080/02640414.2020. 1841396

Zheng, C., Huang, W. Y., Sheridan, S., Sit, C. H. P., Chen, X. K., \& Wong, S. H. S. (2020). Covid19 pandemic brings a sedentary lifestyle in young adults: A cross-sectional and longitudinal study. In International Journal of Environmental Research and Public Health (Vol. 17). https://doi.org/10.3390/ijerph1717603 